\title{
The influence of magnetic field on the growth of tomato (Lycopersicum esculentum) infected with Fusarium oxysporum
}

\author{
Rochmah Agustrina ${ }^{1}$, Endang Nurcahyani ${ }^{1}$, Eko Pramono $^{2}$, Ika Listiana $^{1}$, Eko Nastiti $^{1}$
}

\begin{abstract}
This Previous research suggests that magnetic field (MF) can enhance seedling vigor, growth, and the production of tomato plants. This study examines the influence of MF on the growth of tomato infected by Fusarium oxysporum, fungal pathogen that causes Fusarium wilt in tomatoes. This factorial study arranged in a stripe split plot design. Factors tested consists of long exposure to the MF, M (control; 7'48 "; II'42" and 15'36"), how to infect fusarium, F (through soaking the seeds and by infecting fusarium through the stem at the age 28 days after sowing (das), and soaking the seeds, $\mathrm{S}$ (soaking and without soaking for 15 minutes before MF treatment). Each unit of experiment was repeated 3 times. Parameters measured were percentage of germination, growth rate based on plant height, and fresh weight. Observations were made on the plant until 42 das. Data were analyzed of variance followed by the least significant difference (LSD) test at $\alpha=1$ and 5\%. The results showed that the interaction between $\mathrm{MF}$ and fusarium $(\mathrm{MxF})$, fusarium and soaking (FxS), and MF, fusarium, and soaking $(\mathrm{MxFxS})$ did not produce a different response on all parameters measured. Differences in response to the treatments derived from the treatment of MF (M), Fusarium (F), and the treatment interaction of the MF $x$ soaking $(\mathrm{MxS})$. The MF $(\mathrm{M})$ and the interaction of MF and soaking (MxS) significantly effect on all parameters measured at each measurement. The treatment of Fusarium (F) significantly effect on germination percentage, and fresh weight at 7 das.
\end{abstract}

Keywords - magnetic field, fusarium, germination percentage, growth rate, fresh weight.

\section{INTRODUCTION}

$\mathrm{A}$ 11 living organisms on earth is influenced by factors that exist in the surrounding environment including the Earth's magnetic field, GMF. Thus, the influence of magnetic fields (MF) on the growth and development of plants can not be ignored. GMF is steadily acting on living systems, and is known to influence many biological processes (Kobayashi et al., 2004). Studies on the influence of magnetic fields (MF) in plants have long done (Pittman, 1963; Krylov and Tarakanova, 1960, Murphy, 1942). Although the literature contains research reports that are inconsistent (Harris et al., 2009) but a lot of the result of studies show convincing evidence that the magnetic field is able to increase the variety of phenomena of plant growth and development. Treatment of the MF is known to be able to increase the germination percentage of various types of plants (Mausavizadeh et al., 2013; Pourakbar and Hatami, 2012; Farashas et all, 2011; Aladjadjiyan et al., 2003), germination rate (Mausavizadeh et al., 2013; Vashist and Nagarajan, 2010; Criveanu, and Taralunga. 2006, and Podlesny et al., 2005)

${ }^{1}$ Department of Biology, Faculty of Mathematics and Natural Sciences, Universitas Lampung,

${ }^{1}$ Department of Agronomy, Faculty of Agriculture, Universitas Lampung,

Jalan Prof. Soemantri Brojonegoro No. 1, Bandar Lampung, Indonesia. growth rate of seedling (Mausavizadeh et al., 2013 and Agustrina et al., 2012), dry weight (Shine et al., 2011), nutrient content (Faqenabi et al., 2009 and Esitken and Turan, 2004), and production (De Souza et al., 2005).

An increase in the activity of enzymes during germination in plants (Mausavizadeh et al., 2013; Pourakbar and Hatami, 2012; Reddy et al, 2012; Vashist, and Nagarajan, 2010; and Atak et al., 2007) showed that magnetic field can influence the metabolic processes in cells that have an impact on improving the vigor and growth of plants (Agustrina et al., 2011). On tomatoes, magnetic field treatment in addition to increasing vigor also increases yield (De Souza et al., 2005).

Studies above and many other studies show that the use of the magnetic field with a proper strength of MF energy and treatment can improve plant vigor and yield. However, it is unknown whether the increased vigor and crop yield due to the magnetic field treatment is also followed by the increase in resistance to disease. In this study observed the effect of the MF treatment on tomato plants infected by the pathogenic fungus that causes Fusarium wilt disease, Fusarium oxysporum (Novita 2011 and Sussana et. Al., 2010).

\section{MATERIAL AND METHOD}

Tomato seeds used were obtained from seed merchants with a germination rate of $95 \%$. Seeds to be treated immersion (S1), soaked in tap water for 15 minutes before being given a 0.2 mT MF treatment, while the untreated immersion (S0) directly exposed to a MF. MF treatment is given for 7'48 "(M1); 11'42" (M2) and 15'36 "(M3) and control (M0).

Fusarium monospore used for the treatment of infection Fusarium derived from Fusarium sp. isolate provided by IPB Culture collection. Fusarium infection through the roots is done by soaking the seeds that have been treated by MF in the suspension containing monospora Fusarium sp. with a density of $1 \times 107$ for 12 hours. While Fusarium infection on the stem is done by injecting about $50 \mathrm{ml}$ suspension of monospora Fusarium on tomato stems at the age of 28 days after sowing (das). All the seeds were treated fusarium planted in both sterile and non-sterile soil. The marking for the treatment of Fusarium are as follows. F0 $=$ no infection Fusarium grown in sterile soil, F1 = no infection Fusarium grown in non-sterile soil, F2 = infection through seed soaking in monospore Fusarium suspension, grown in setrile soil, F3 = infection through seed soaking in monospore Fusarium suspension, grown in non-steriel soil, 
F4 = infection through the stem, grown in sterile soil,and F5 = infection through the stem, grown in non-sterile soil. Planting and maintenance of the plant following the planting and maintenance of tomato plants as is usually done by farmers.

The plant responses to the treatments of MF, fussarium, and seed soaking was observed by measuring the percentage of seed germination, plant growth rate on plant height, fresh weight, and dry weight.

\section{RESULTS}

The growth response in this study was observed on all plants that survive from the results of treatment with Fusarium infection by soaking the seeds in Fusarium monospore suspension. Treatment MF (M) and Fusarium infections (F) causes the difference in the percentage of germination, as well as treatment of the interaction between the MF and immersion (MXS). The interaction between the MF and F (MXF); the interaction between the $\mathrm{F}$ and $\mathrm{S}(\mathrm{SXF})$; and the treatment of $\mathrm{MF}$ interaction, $\mathrm{F}$, and $\mathrm{S}(\mathrm{MxFxS})$ did not result in any significant growth response.

Such as the results of previous studies (Agustrina et al., 2012; El Yazied et al., 2011, De Souza et al., 2005), treatment of $\mathrm{MF}$ affect the germination, growth rate, fresh weight, and dry weight (Figures 1 to 4 ). However, in this study MF treatment reduced the percentage of germination (Fig. 1a). Although the interaction of $\mathrm{MxF}$ not affect germination percentage, but the decline in the percentage of germination resulted in MF treatment in the study is thought to be due to the presence of $\mathrm{F}$ treatment especially in the treatment of F2 and F3, where the seeds for the treatment of F2 and F3 soaked before sowing. Seeding both in sterile soil (F2) or unsterile soil cause a decrease in the percentage of germination (Fig 1b). In the treatment of F4 and F5, the seeds have not been treated with $\mathrm{F}$, so the percentage of germination at F4 and F5 is the response to treatment of $\mathrm{MF}$ and $\mathrm{S}$ only. Technology Acceptance Model (TAM) Theory.

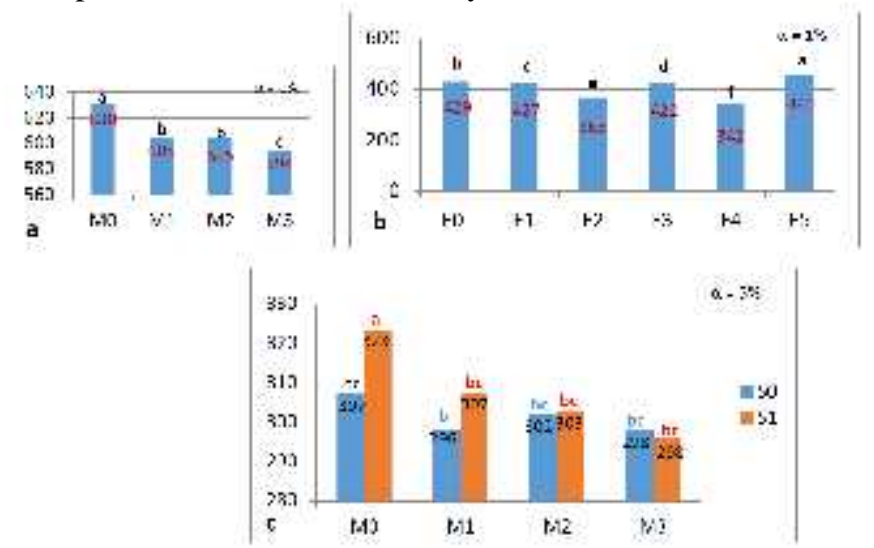

Fig 1. Germination percentage of seed (\%) under MF treatment (a), treatment of fusarium infection (b), and interaction MF and Fusarium, MxF (c). M = MF exposure. M0 = control, M1 = 7'48 ", M2 = II'42" and, M3 $=15^{\prime} 36^{\prime \prime} . \mathrm{F}=$ Fusarium infection. F0 = control, grown in sterile soil, F1 = control, grown in non- sterile soil, F2 = infection through seed soaking in monospore Fusarium suspension, grown in setrile soil, F3 = infection hrough seed soaking in monospore Fusarium suspension, grown in non- stetrile soil, F4 = infection through the stem, grown in sterile soil, and F5 = infection through the stem, grown in non-setrile soil
The response of the fresh weight at 7 das (Fig 3a.1 to 3a.3) in the treatment of MF, Fusarium infections (F), and immersion (S) showed the same response as the response percentage of germination above. At 7 das, MF treatment, Fusarium infections, and the interaction of treatment $\mathrm{MxS}$ cause differences in fresh weight of seedlings. However, for the fresh weight of seedlings, the treatment of $\mathrm{MF}$ and the interaction of $\mathrm{MxS}$ treatment showed similar results with previous studies that prove that the treatment of MF and seed immersion (S) increase the fresh weight of seedlings (Agustrina et al., 2012; El Yazied et al., 2011, De Souza et al., 2005). These results strengthening the suspicion that the treatment effect of MF in improving responses to the growth of tomato plants are able to survive against Fusarium infection has not disappeared, so the fresh weight of seedlings from seeds treated MF is greater than the control.

In this study, all treatments MF increase the growth rate as well as the interaction of treatment $\mathrm{MxS}$ on growth period $7-$ 28 das, particularly in the treatment of MF exposure for 7'48 ". The results are consistent with results of other studies (Agustrina et al. 2012; El Yazied et al., 2011, De Souza et al., 2005) which proves that the MF and soaking treatment can improve the seedling growth.

Water plays an important role in the process of germination and cell enlargement. The MF affects the physical properties of water chemistry that lowers the surface tension and increases the viscosity of the water so it is more stable because molecular energy becomes lower and higher activation energy (Cai et al., 2009). MF treatment accelerate the rate of hydration into germ cells (Agustrina et al., 2011 and Shine et al., 2011). Soaking the seeds of tomatoes for 15 minutes before treatment (S1) exposure of MF resulted in germ cells hydrated earlier than treatment S0, meaning that the metabolism of germination in treatment $\mathrm{S} 1$ has been in progress when treated with MF and finally the treatment of MF accelerate the metabolism of ongoing growth (Agustrina et al., 201). The results of measurements on the growth rate (Fig. 2a) and fresh weight (Fig. 3b) of tomato plants showed that the treatment of MF and immersion (S) can increase growth of tomato plants that can withstand the treatment of Fusarium infection.

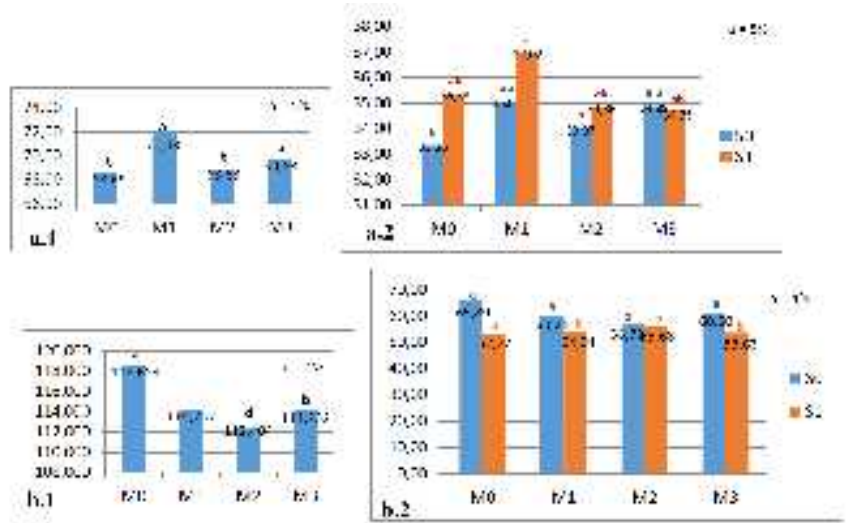

Fig. 2. The growth rate of the growth period 7-28 das (a) and $7-42$ das (b) under MF treatment (a.1 and b.1) and interaction treatment of MxS (a.2 and b.2). $\mathrm{M}=\mathrm{MF}$ exposure. $\mathrm{M} 0=$ control, $\mathrm{M} 1=7^{\prime} 48$ ", $\mathrm{M} 2=\|^{\prime} 42^{\prime \prime}$ and, $\mathrm{M} 3=$ $15^{\prime} 36$ ". S = immersion. S0 = seeds without soaking, S1 = soaking the seeds for $15^{\prime}$. The unit measurement is $\mathrm{cm} \mathrm{day}^{-1}$ 
The response rate of growth (Fig. 2b) and fresh weight (Fig $3 a)$ in the growth period 7-42 das growth showed differences in the results with measurements on growth period 7-28 das.

Differences in the measurement result is believed to be due to changes in metabolism that is from metabolism process for the vegetative phase to the generative phase. At 42 das, tomato plants have already entered the generative phase. In the generative phase, the rate of plant growth slows as it enters the stationary growth phase.

In the generative phase, results of photosynthesis more used to establish food storage tissues rather than to the formation of vegetative tissues such as leaves and stems. Koelewijn (2004) generative phase. The process of change in the metabolism of the vegetative phase to the generative phase seems to be rapidly taking place in the S1 treatment where seeds are soaked before treated (Fig. 2b.2). Several studies showed treatment before MF increase crop production (Faqanabi et al., 2009; De Souza, et al., 2005; and Kordas et al., 2002). Of all the data obtained, Fusarium infection was not significant effect on the growth of tomatoes unless reduced the percentage of germination, seedling fresh weight (7 das). Fusarium infection in the plant stem at the age of 28 das does not affect the growth response, both on the growth rate (Fig. $2 \mathrm{~b}$ ) and the fresh weight (Fig 3c) in the period of plant growth 7-42 das.

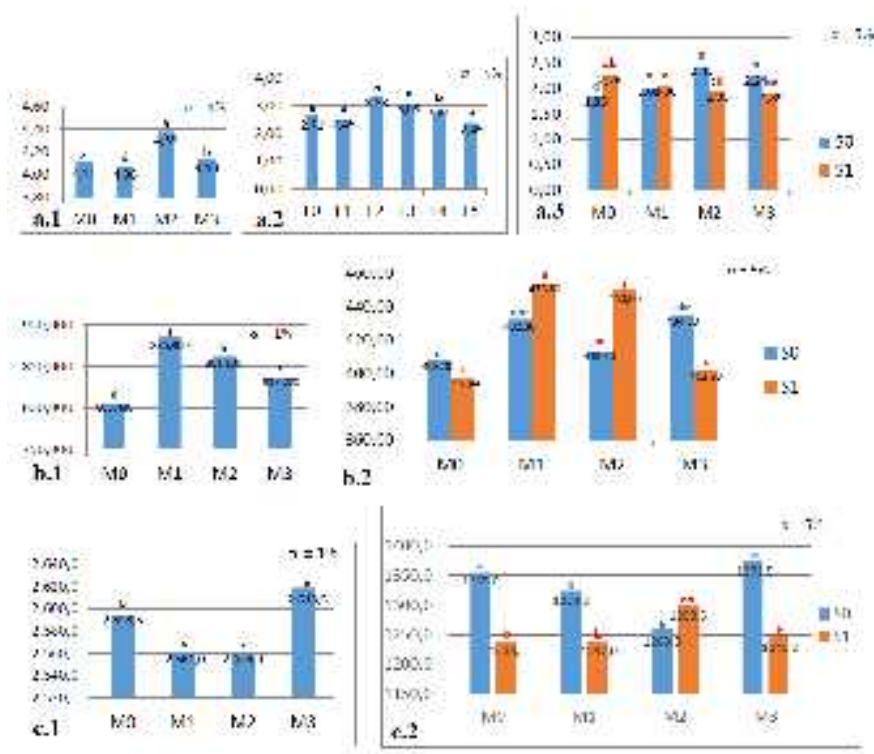

Fig. 3. Tomatoes fresh weight (gram) on 7 das (a) and 28 das (b), and 42 day(c) under MF treatment (a.1, b.1, dan c.1), Fusarium infection (a.2), and interaction treatment of $\mathrm{MxS}$ (a.3, b2, and c.2). $\mathrm{M}=\mathrm{MF}$ exposure. $\mathrm{M0}=$ control, M1 = 7'48 ", M2 = 11'42" and, M3 = 15'36 ". S = immersion. S0 = seeds without soaking, $\mathrm{S} 1=$ soaking the seeds for $15^{\prime}$. F0 = control, grown in sterile soil, $\mathrm{F} 1$ = control, grown in non- sterile soil, $\mathrm{F} 2$ = infection hrough seed soaking in monospore Fusarium suspension, grown in sterile soil, F3 = infection through seed soaking in monospore Fusarium suspension, grown in non-sterile soil, F4 = infection through the stem, grown in sterile soil, and F5 $=$ infection through the stem, grown in non-sterile soil.

Data reduction in germination percentage, fresh weight and growth rate above still can not be assured yet that the treatment of MF in this study enhance the growth and resistance of tomato plants. The possibilities that can be drawn from these results are:

a. Pathogenicity of Fusarium isolates used to get monospore Fusarium weak, so although soaking seeds by Fusarium monospore suspension reduced the percentage of germination and fresh weight statistically significanse, but the decline is relatively small (4.7 to $14.92 \%$, Fig. 1b, F0 to F3)

b. Fusarium infection on the stem of the plant when the plant aged 28 das ineffective in causing Fusarium wilt disease.

\section{CONCLUSION}

Treatment of MF (M) on the seed infected with a suspension of Fusarium monospore by soaking the seeds do not increase the percentage of germination. Fusarium infection decreases the germination percentage, but there is no effect of the treatment interaction of $\mathrm{MxF}$ in the percentage of germination. MF treatment and the treatment interaction of $\mathrm{MxS}$ increase the growth rate and it is thought to increase the speed of change in metabolic processes of the vegetative phase to the generative phase. Because the entire observation was done on plants that survived from Fusarium infection, and of all the measured parameters indicate an increase in the growth response, then these results can provide guidance that MF may improve the growth of tomato plants that survived from the attack of Fusarium infection. However, further studies need to be done to ensure the above results and the increased resistance of plants against pathogen attack can be proven.

\section{ACKNOWLEDGEMENT}

The data presented in this paper is part of the data of a research project funded by the Directorate General of Higher Education through a program of competition grant 'Strategi Nasional' in 2014-2015

\section{REFERENCES}

[1] Agustrina, R., T.Tripeni $\mathrm{H}$ andayani, S. Wahyuningsih, dan $\mathrm{O}$ Prasetya. 2012. Pertumbuhan Tanaman Tomat (Lycopersicum esculentum Mill.) di Bawah Perlakuan Medan Magnet 0,2 mT. Prosiding SNSMAIP III. Unila - Bandarlampung. Pp.: 277 - 281

[2] Agustrina, Rochmah, Tunjung Tripeni, dan Eti Ernawiati. 2011 Anatomi Kecambah Tomat Yang Diberi Perlakuan Medan Magnet 0,2 mT. Prosiding: Seminar Nasional Sains \& Teknologi - IV. Universitas Lampung, Bandar Lampung: 656-646.

[3] Aladjadjiyan, Anna dan Teodora Ylieve. 2003. Influence of Stationary Magnetic Field on The Early Stages of The Development of Tobacco Seeds (Nicotiana tabacum L.). Journal Central Europian Agriculture. Vol. 4. No. 2. p131-137.

[4] Atak, O., O. Celik, A. Olgun, S. Alikamanoglu, A. Rzakoulieva. 2007. Ffect Of Magnetic Field On Peroxidase Activities Of Soybean Tissue Culture. Biotechnol. \& Biotechnol. Eq. 21/2007/2: 166 - 171

[5] Chai, R., H. Yang, J. He., dan W. Zhu. 2009. The effects of magnetic field on water molecular hydrogen bonds. Journal of Molecular Structure. 938: 15 - 19.

[6] Criveanue, H.R. dan Taralunga, G. 2006. Influence of magnetic fields of variable intensity on behaviour of some medicinal plants. Journal of Central Euro Agricultura, Vol 7, 4, pp 643-648. 
[7] De Souza, A., D. García, L. Sueiro, L. Licea dan E. Porras. 2005. PreSowing Magnetic Treatment of Tomato Seeds: Effects on The Growth and Yield of Plants Cultivated Latein The Season. Spanish Journal of Agricultural Research. 3(1), 113-122

[8] Esitken, A dan M. Turan. 2004. Alternating Magnetic Field Effects on Yeld and Plant Nutrient Element Composition of Strawberry (Fragaria xananassa cv. Camarosa). Acta Agriculture Scandinavica, B, Vol 54 No 3 p.135-139

[9] Farashah, H.D., R. Tavakkol A., F. Sharifzadeh, and S. Chavoshinasab. 2011. Germination improvement and $\alpha$-amylase and $\beta$-1,3-glucanase activity in dormant and non- dormant seeds of Oregano (Origanum vulgare). AJCS 5(4):421-427

[10] Faqenabi , F., M. Tajbakhsh , I. Bernoosi, M. Saber-Rezaii , F. Tahri S. Parvizi , M. Izadkhah , A. H. Gorttapeh and H. Sedqi . 2009. The Effect of Magnetic Field on Growth,

[11] Development and Yield of Safflower and Its Comparison with Others Treatments. Research Journal of Biological Sciences. 4(2): 174-178

[12] Harris S. R., Henbest K. B., Maeda K., Pannell J. R., Timmel C. R., Hore P. J., et al. (2009). Effect of magnetic fields on cryptochromedependent responses in Arabidopsis thaliana. J. R. Soc. Interface 6, 1193-1205

[13] Koelewijn, Hans Peter. 2004. Rapid change in relative growth rate between the vegetative and reproductive stage of the life cycle in Plantago coronopus. New Phytologist. 163: 67-76

[14] Kobayashi M., Soda N., Miyo T., Ueda Y. (2004). Effects of combined DC and AC Magnetic Felds on germination of hornwort seeds. Bioelectromagnetics 25, 552-55

[15] Krylov, A. V., and G. A. Tarakanova. 1960. Magnetotropism of plants and its nature. Plant Physiol. 7 (2) :156-160.

[16] Mausavizadeh, Seyyed Javad Mousavizadeh, Shahram Sedaghathoor, Abdolrahman Rahimi, Haydeh Mohammadi. 2013. Germination parameters and peroxidase activity of lettuce seed under stationary magnetic field. International Journal of Biosciences. Vol. 3, No. 4, p. 199-207
[17] Murphy, J. B., 1942. "The Influence of Magnetic Fields Germination," Am. J. Botan. (Suppl.) 29:155, 1942.

[18] Novita, T., 2011. Trichoderma sp. dalam Pengendalian Penyakit Layu Fusarium pada Tanaman Tomat (Trichoderma sp. in Controlling Tomato Fusarium Wilt Disease). Biospecies, Volume 4 No. 2, Juli 2011, hlm. 27 - 29 Odhiambo, J.O., F.G. Ndiritu, and I.N. Wagara 2009. Effect of static electromagnetic fields at 24 hours incubation on the germination of rose coco beans (Phaseolus vulgaris). Romanian J. Biophys., 19 (2) : 135-147

[19] Pittman, U.J. 1963. Manetism and Plant Growth: I. Effect on Germination and Early Growth Of Cereal Seeds. Canadian Journal of Plant Science. 43: 513-518

[20] Podlesny J, Pietruszewski S, Podlesna A (2005) Influence of magnetic stimulation of seeds on the formation of morphological features and yielding of the pea. Int. Agrophysics. 19: 61-68

[21] Pourakbar, Latifeh and Sepideh Hatami, 2012. Exposure of Satureia hortensis L seeds to magnetic fields: effect on germination, growth characteristics and activity of some enzymes. Journal of Stress Physiology \& Biochemistry, Vol. 8 No. 4 2012, pp. 191-198

[22] Reddy, K. Venkateswar, S.R. Resma, S. Jareena, and N. Nagaraju. 2012. Exposure Greengram Seed (Vigna radiate var. radiata) to static Magnetic Field: Effect on Germinase and $\alpha$-Amylase Activity. Res. J. Seed. Science: $1-9$

[23] Shine M., Guruprasad K., Anand A. (2011). Enhancement of germination, growth, and photosynthesis in soybean by pre-treatment of seeds with magnetic field. Bioelectromagnetics 32, 474-484 10.

[24] Sarawa and A.R. Baco. 2014 Partisi Fotosintat Beberapa Kultivar Kedelai Glicine max. (L.) Merr.) Pada Ultiso. Jurnal Agroteknos. Vol. 4 No. 3. Hal 152-159

[25] Susanna, Tjut Chamzurni, and Arisandi Pratama. 2010. Dosis Dan Frekuensi Kascing Untuk Pengendalian Penyakit Layu Fusarium Pada Tanaman Tomat. J. Floratek 5: 152 - 163

[26] Vashist, A., J.K. Joshi, and R. Singh, 2011. Characterization of Water Uptake ang Distribution in cheekpea (Cicer arietinum L.) Seed During Gerination by NMR Spectroscopy). Journal oJournal of Bioteknology. Vol. 11 (59): 21286-12297 